\title{
Novel Technology for Chlorination of Niobium and Tantalum Oxides and Their Low-Grade Ore Concentrates
}

\author{
B. A. Shainyan, ${ }^{1}$ Yu. S. Danilevich, ${ }^{1}$ Yu. L. Garmazov, ${ }^{2}$ A. L. Finkelstein, ${ }^{3}$ T. S. Aisueva, ${ }^{3}$ V. \\ K. Turchaninov ${ }^{4}$
}

${ }^{1}$ A. E. Favorsky Irkutsk Institute of Chemistry of Siberian Branch of Russian Academy of Sciences, 1 Favorsky Street 664033, Irkutsk, Russia.

E-mail: bagrat@irioch.irk.ru

2 “Tantal” Co. Ltd., Irkutsk, Russia

${ }^{3}$ A. P. Vinogradov Institute of Geochemistry of Siberian Branch of Russian Academy of Sciences, Irkutsk, Russia

${ }^{4}$ Irkutsk State Technical University, Irkutsk, Russia

\begin{abstract}
A novel energy-economic and environmentally benign technological procedure for chlorination of niobium and tantalum oxides as well as their low-grade ore concentrates was elaborated. The process is based on using carbon tetrachloride or silicon tetrachloride as a chlorinating agent under pressure. It proceeds at moderate temperatures and is free from the shortcomings of conventional carbochlorination processes such as the use of chlorine gas at very high temperatures and formation of toxic products and ozone depleting agents (phosgene, carbon monoxide, chlorohydrocarbons).
\end{abstract}

Keywords: niobium oxide, tantalum oxide, carbochlorination.

\section{INTRODUCTION}

Direct chlorination of refractory metal oxides $\mathrm{Nb}_{2} \mathrm{O}_{5}$ and $\mathrm{Ta}_{2} \mathrm{O}_{5}$ to their pentachlorides is thermodynamically unfavorable and takes place only in the presence of a reducing agent binding the released oxygen. The process is usually carried out in the presence of different forms of carbon [1-8] or carbon monoxide $[9,10]$ and is known as carbochlorination process. In all cases the reaction is carried out at a high temperature, up to $1000^{\circ} \mathrm{C}$, therefore, the process is very energy consuming. Processes using one reagent acting as both the chlorinating and the reducing agent are also known, for example, carbochlorination of $\mathrm{Nb}_{2} \mathrm{O}_{5}$ [11] or $\mathrm{Ta}_{2} \mathrm{O}_{5}$ [12] with carbon tetrachloride vapors at temperatures up to $580^{\circ} \mathrm{C}$. Note that chlorination with $\mathrm{CCl}_{4}$ proceeds under milder conditions than with chlorine, although the temperature is still rather high. Moreover, the use or formation such toxic and ozone depleting compounds as chlorine, phosgene and chlorocarbons during the processes makes them dangerous and environmentally harmful.

The autoclave technology for carbochlorination of niobium and tantalum oxides by the use of carbon tetrachloride as a chlorinating and reducing agent in the original two-autoclave apparatus 
was also elaborated [13]. In this paper we describe the results of carbochlorination of niobium and tantalum oxides and their ore concentrates with carbon tetrachloride as well as the recently patented $[14,15]$ novel chlorination system based on silicon tetrachloride, which is free of the above-mentioned drawbacks and allows to carry out the process under even milder conditions and make it free from formation of toxic and ozone depleting compounds like phosgene and chlorocarbons. A comparison is made of the two chlorination systems, $\mathrm{CCl}_{4}$ and $\mathrm{SiCl}_{4}$, including the thermodynamic analysis of their reactions with the metal oxides.

\section{EXPERIMENTAL}

\subsection{Materials}

The experiments were performed on several types of materials. (1) Technical grade metal oxides $\mathrm{Nb}_{2} \mathrm{O}_{5}$ and $\mathrm{Ta}_{2} \mathrm{O}_{5}$ prepared by sulfuric acid leaching of niobium- and tantalum-containing ores and containing about $80-90 \%$ of the corresponding metal oxide. (2) Mixed niobium-tantalum ore concentrate that came from "Zashikhinskoe" deposit (Irkutsk region, Russia) and contained from 2.3 to $16.7 \% \mathrm{Nb}$ and from 0.1 to $7.2 \%$ Ta. (3) Niobium ore concentrate that came from "Tatarskoe" deposit (Krasnoyarsk region, Russia) and contained 3.7\% Nb. Commercial $\mathrm{CCl}_{4}$ and $\mathrm{SiCl}_{4}$ were used without further purification. Acetonitrile was dried by distillation over $\mathrm{P}_{2} \mathrm{O}_{5}$.

\subsection{Equipment}

The chlorination experiments without mixing were performed in stainless steel bombs of 80-100 $\mathrm{mL}$ capacity. The experiments with mixing were performed in the two-autoclave equipment schematically shown in Fig. 1. It includes a high-pressure autoclave 1 of 150-200 mL capacity, made of austenitic steel X18H10T, working at up to $100 \mathrm{~atm}$ and $500^{\circ} \mathrm{C}$. The autoclave is heated by an electric oven consisting of a tubular heater 2 of 0.5 kilowatt power and heat-insulating mantle 3. The temperature is regulated by autotransformer $\mathbf{4}$ and controlled by thermocouple $\mathbf{5}$ and potentiometer $\mathbf{6}$. The reaction mixture is stirred by rocking of the working autoclave. The rocking mechanism consists of electric motor 7, reduction worm-gear $\mathbf{8}$ and crank-connecting rod system 9. The rate of rocking is $40 \mathrm{cpm}$. The products of chlorination were filtered through pipeline 10 under the pressure developed in the working autoclave $\mathbf{1}$ into the receiving autoclave 11 whose design and characteristics are similar to those of autoclave $\mathbf{1 .}$

\subsection{Chlorination Procedure}

2.3.1. Chlorination of niobium oxide with $\mathbf{C C l}_{4}$. The experiments were carried out in a twoautoclave apparatus. Working autoclave of $200 \mathrm{~mL}$ capacity was charged with $25 \mathrm{~g}$ of $\mathrm{Nb}_{2} \mathrm{O}_{5}$ and $150 \mathrm{~mL}$ of $\mathrm{CCl}_{4}$, sealed, heated to $250-290^{\circ} \mathrm{C}$ and kept for $2 \mathrm{~h}$ at this temperature being stirred by rocking. Then the working autoclave contents was transferred through the filter into the receiving autoclave, which was cooled and opened. The precipitate formed was filtered off and thoroughly washed with acetonitrile to give almost colorless niobium oxychloride $\mathrm{NbOCl}_{3}$. The filtrate $\left(\mathrm{CCl}_{4}\right)$ was evaporated to give $\mathrm{NbCl}_{5}$.

2.3.2. Chlorination of columbites and pyrochlores with $\mathbf{C C l}_{\mathbf{4}}$. The experiments were similar to those above for chlorination of $\mathrm{Nb}_{2} \mathrm{O}_{5}$ with $\mathrm{CCl}_{4}$, the temperature was maintained within 250 $290^{\circ} \mathrm{C}$. The results are given in Table 1 . 


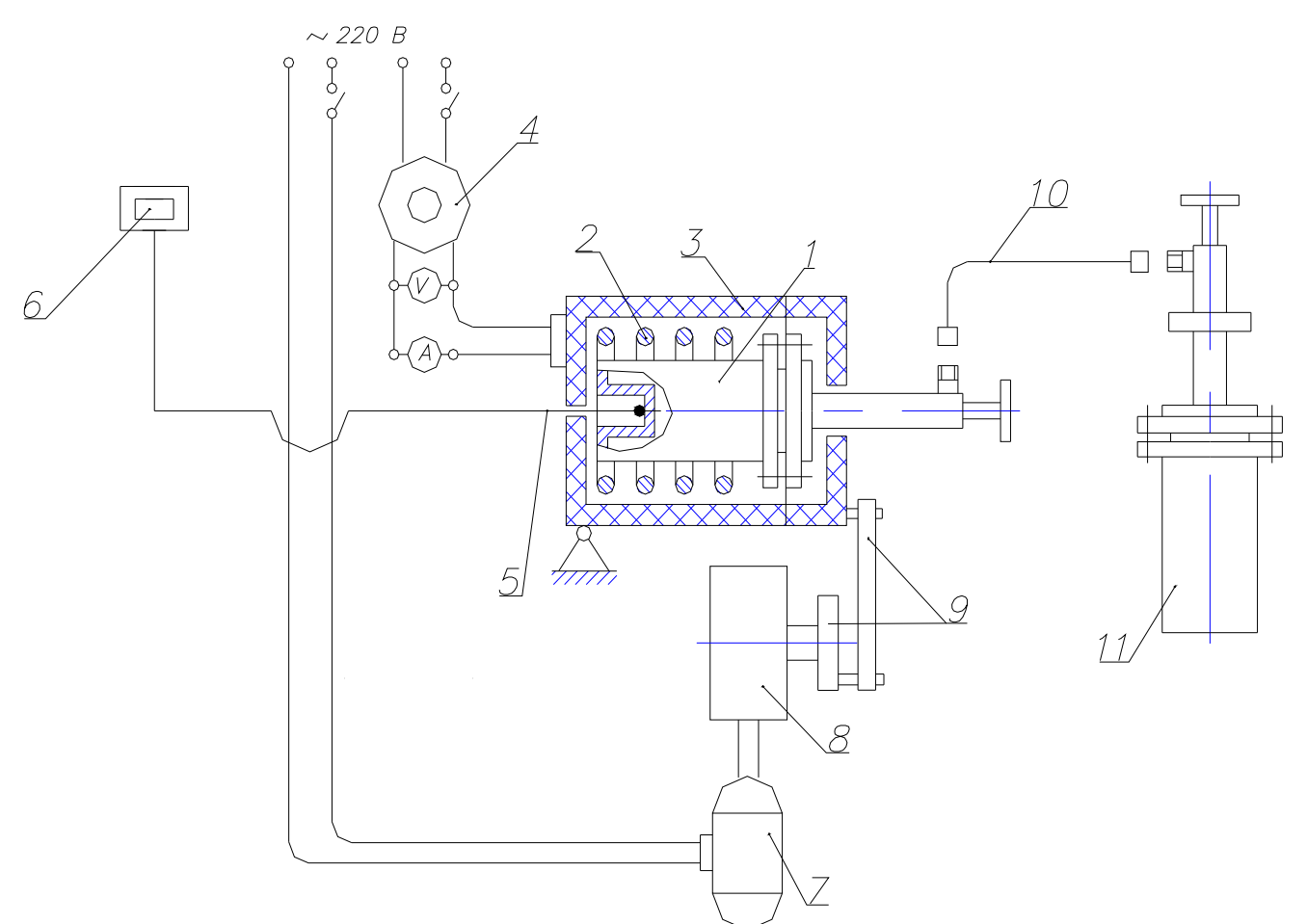

Fig. 1. Schematic diagram of the experimental two-autoclave unit. (1) working autoclave; (2) tubular heater; (3) heat-insulating mantle; (4) autotransformer; (5) thermocouple; (6) potentiometer; (7) electric motor; (8) reduction worm-gear; (9) crank-connecting rod system; (10) pipeline connecting the working and receiving autoclaves; (11) receiving autoclave.

Table 1. Contents of niobium and tantalum after chlorination of columbites and pyrochlores with $\mathrm{CCl}_{4}$.

\begin{tabular}{l|l|c|c}
\hline Sample & Metal & $\begin{array}{c}\text { Ore } \\
\text { concentrate }\end{array}$ & $\begin{array}{c}\text { Cake after } \\
\text { chlorination }\end{array}$ \\
\hline No. 1 & $\mathrm{Nb}$ & 7.74 & $\mathrm{n} / \mathrm{d}$ \\
& $\mathrm{Ta}$ & 0.78 & $\mathrm{n} / \mathrm{d}$ \\
\hline No. 2 & $\mathrm{Nb}$ & 16.70 & $\mathrm{n} / \mathrm{d}$ \\
& $\mathrm{Ta}$ & 7.15 & $\mathrm{n} / \mathrm{d}$ \\
\hline No. 3 & $\mathrm{Nb}$ & 2.29 & $\mathrm{n} / \mathrm{d}$ \\
& $\mathrm{Ta}$ & 2.55 & 0.149 \\
\hline No. 4 & $\mathrm{Nb}$ & 7.83 & $\mathrm{n} / \mathrm{d}$ \\
& $\mathrm{Ta}$ & $\mathrm{n} / \mathrm{d}$ & $\mathrm{n} / \mathrm{d}$ \\
\hline
\end{tabular}

2.3.3. Chlorination of metal oxides with $\mathrm{SiCl}_{4}$. Stainless steel bomb of $80-100 \mathrm{~mL}$ capacity was charged with $10 \mathrm{~g}$ of technical grade metal oxide dried at $200^{\circ} \mathrm{C}$ and poured over with $30-50$ $\mathrm{mL}$ of $\mathrm{SiCl}_{4}$. The bomb was sealed, placed into an electric tubular oven and kept at $210-280^{\circ} \mathrm{C}$ for $2-4 \mathrm{~h}$ being periodically shaken. Then the bomb was cooled, opened and the contents 
filtered. Metal chlorides are practically insoluble in $\mathrm{SiCl}_{4}$, so their concentration in the filtrate was negligible. The residue on the filter was treated with dry acetonitrile and filtered from $\mathrm{SiO}_{2}$. The filtrate was evaporated to give 15.6-17.6 g of crude metal pentachloride as greenish-yellow residue. The results of chlorination under various conditions and the content of different oxides before and after chlorination are given in Tables $2-5$.

Table 2. Results of chlorination of technical grade $\mathrm{Nb}_{2} \mathrm{O}_{5}$ with $\mathrm{SiCl}_{4}$ under various conditions.

\begin{tabular}{c|c|c|c|c}
\hline Run & Temperature, ${ }^{\circ} \mathrm{C}$ & Molar ratio $\mathrm{Nb}_{2} \mathrm{O}_{5}: \mathrm{SiCl}_{4}$ & Time, $\mathrm{h}$ & Yield of Nb chlorides, $(\%)$ \\
\hline 1 & 180 & $1: 3$ & 4 & - \\
2 & 205 & $1: 5$ & 3 & 15 \\
3 & 210 & $1: 3$ & 7 & 45 \\
4 & 210 & $1: 10$ & 6 & 30 (without shaking) \\
5 & 210 & $1: 10$ & 5 & 72 (with shaking) \\
6 & 210 & $1: 3$ & 4 & 75 \\
7 & 210 & $1: 5$ & 1 & 90 \\
8 & 245 & & & 73 \\
\hline
\end{tabular}

Table 3. Composition of various products (\%) from chlorination of technical grade $\mathrm{Nb}_{2} \mathrm{O}_{5}$ (from XRF).

\begin{tabular}{|c|c|c|c|c|}
\hline \multirow[b]{2}{*}{ Oxide } & \multirow{2}{*}{$\begin{array}{l}\text { Starting } \\
\text { material }\end{array}$} & \multicolumn{3}{|c|}{ After chlorination (run 5 from Table 2) } \\
\hline & & $\begin{array}{l}\text { Residue insoluble } \\
\text { in MeCN }\end{array}$ & $\begin{array}{l}\text { Residue after } \\
\text { sublimation }\end{array}$ & $\begin{array}{c}\mathrm{NbCl}_{5} \\
\text { sublimed }\end{array}$ \\
\hline $\mathrm{WO}_{3}$ & 6.26 & 0.111 & 8.41 & 2.13 \\
\hline $\mathrm{SiO}_{2}$ & 0.682 & $\sim 90$ & 2.42 & 0.36 \\
\hline $\mathrm{ZrO}_{2}$ & 0.348 & 0.055 & $\mathrm{n} / \mathrm{d}$ & 0.207 \\
\hline $\mathrm{Fe}_{2} \mathrm{O}_{3}$ & 7.64 & 1.96 & 13.4 & $\mathrm{n} / \mathrm{d}$ \\
\hline $\mathrm{UO}_{2}$ & 0.395 & 0.050 & 0.922 & $\mathrm{n} / \mathrm{d}$ \\
\hline $\mathrm{SO}_{3}$ & 1.95 & 1.44 & 0.513 & $\mathrm{n} / \mathrm{d}$ \\
\hline $\mathrm{ZnO}$ & 0.196 & 0.012 & 0.413 & $\mathrm{n} / \mathrm{d}$ \\
\hline $\mathrm{Cr}_{2} \mathrm{O}_{3}$ & $\mathrm{n} / \mathrm{d}$ & 0.047 & 0.354 & $\mathrm{n} / \mathrm{d}$ \\
\hline $\mathrm{CaO}$ & 0.40 & 0.10 & 0.33 & $\mathrm{n} / \mathrm{d}$ \\
\hline $\mathrm{NiO}$ & 0.072 & 0.020 & 0.263 & $\mathrm{n} / \mathrm{d}$ \\
\hline $\mathrm{MnO}$ & 0.437 & 0.158 & 0.237 & $\mathrm{n} / \mathrm{d}$ \\
\hline $\mathrm{P}_{2} \mathrm{O}_{5}$ & 1.03 & 0.723 & 0.074 & $\mathrm{n} / \mathrm{d}$ \\
\hline $\mathrm{CuO}$ & $\mathrm{n} / \mathrm{d}$ & $\mathrm{n} / \mathrm{d}$ & 0.050 & $\mathrm{n} / \mathrm{d}$ \\
\hline $\mathrm{PbO}$ & $\mathrm{n} / \mathrm{d}$ & $\mathrm{n} / \mathrm{d}$ & 0.029 & $\mathrm{n} / \mathrm{d}$ \\
\hline $\mathrm{ThO}_{2}$ & $\mathrm{n} / \mathrm{d}$ & 0.011 & 0.026 & $\mathrm{n} / \mathrm{d}$ \\
\hline $\mathrm{SnO}_{2}$ & 2.21 & 2.21 & $\mathrm{n} / \mathrm{d}$ & $\mathrm{n} / \mathrm{d}$ \\
\hline $\mathrm{As}_{2} \mathrm{O}_{3}$ & 5.33 & 0.804 & $\mathrm{n} / \mathrm{d}$ & $\mathrm{n} / \mathrm{d}$ \\
\hline $\mathrm{Al}_{2} \mathrm{O}_{3}$ & 0.226 & 0.173 & $\mathrm{n} / \mathrm{d}$ & $\mathrm{n} / \mathrm{d}$ \\
\hline
\end{tabular}


Table 4. Results of chlorination of technical grade $\mathrm{Ta}_{2} \mathrm{O}_{5}$ with $\mathrm{SiCl}_{4}$ under various conditions.

\begin{tabular}{c|c|c|c|c}
\hline Run & Temperature, ${ }^{\circ} \mathrm{C}$ & Molar ratio $\mathrm{Ta}_{2} \mathrm{O}_{5}: \mathrm{SiCl}_{4}$ & Time, $\mathrm{h}$ & Yield of Ta chlorides, $(\%)$ \\
\hline 1 & 210 & $1: 10$ & 7 & 23 \\
2 & 245 & $1: 12.5$ & 5 & 73 \\
3 & 245 & $1: 12.5$ & 7 & 100 \\
4 & 280 & $1: 10$ & 2 & 82 \\
5 & 280 & $1: 18$ & 2 & 32 \\
6 & 280 & $1: 18$ & 7 & 78 \\
7 & 300 & $1: 12.5$ & 1 & 69 \\
\hline
\end{tabular}

Table 5. Composition of various products (\%) from chlorination of technical grade $\mathrm{Ta}_{2} \mathrm{O}_{5}$ (from $\mathrm{XRF}$ ).

\begin{tabular}{c|c|c|c|c}
\hline \multirow{2}{*}{ Oxide } & \multirow{2}{*}{$\begin{array}{c}\text { Starting } \\
\text { material }\end{array}$} & \multicolumn{3}{|c}{ After chlorination (run 4 from Table 4) } \\
\cline { 3 - 5 } & $\begin{array}{c}\text { Residue insoluble } \\
\text { in MeCN }\end{array}$ & $\begin{array}{c}\text { Residue after } \\
\text { sublimation }\end{array}$ & $\begin{array}{c}\mathrm{TaCl}_{5} \\
\text { sublimed }\end{array}$ \\
\hline $\mathrm{SiO}_{2}$ & $\mathrm{n} / \mathrm{d}$ & 83.5 & 1.75 & 1.98 \\
$\mathrm{WO}_{3}$ & 1.35 & 0.126 & 0.378 & 0.52 \\
$\mathrm{CuO}$ & $\mathrm{n} / \mathrm{d}$ & 0.098 & 0.291 & 0.287 \\
$\mathrm{Fe}_{2} \mathrm{O}_{3}$ & 0.995 & 0.442 & 2.06 & $\mathrm{n} / \mathrm{d}$ \\
$\mathrm{Cr}_{2} \mathrm{O}_{3}$ & 0.0288 & 0.135 & 0.249 & $\mathrm{n} / \mathrm{d}$ \\
$\mathrm{CaO}$ & 0.139 & $\mathrm{n} / \mathrm{d}$ & 0.179 & $\mathrm{n} / \mathrm{d}$ \\
$\mathrm{NiO}$ & $\mathrm{n} / \mathrm{d}$ & 0.030 & 0.172 & $\mathrm{n} / \mathrm{d}$ \\
$\mathrm{MnO}$ & 0.364 & 0.078 & 0.073 & $\mathrm{n} / \mathrm{d}$ \\
$\mathrm{P}_{2} \mathrm{O}_{5}$ & 0.107 & 0.321 & $\mathrm{n} / \mathrm{d}$ & $\mathrm{n} / \mathrm{d}$ \\
$\mathrm{SO}_{3}$ & 0.181 & 0.207 & $\mathrm{n} / \mathrm{d}$ & $\mathrm{n} / \mathrm{d}$ \\
$\mathrm{Al}_{2} \mathrm{O}_{3}$ & 0.106 & 0.1 & $\mathrm{n} / \mathrm{d}$ & $\mathrm{n} / \mathrm{d}$ \\
$\mathrm{As}_{2} \mathrm{O}_{3}$ & 0.0934 & $\mathrm{n} / \mathrm{d}$ & $\mathrm{n} / \mathrm{d}$ & $\mathrm{n} / \mathrm{d}$ \\
\hline
\end{tabular}

2.3.4. Chlorination of low-grade niobium ore concentrate with $\mathrm{SiCl}_{4}$. The experiments were similar to those with $\mathrm{CCl}_{4}$. Working autoclave of $200 \mathrm{~mL}$ capacity was charged with $80 \mathrm{~g}$ of the ore concentrate dried at $130^{\circ} \mathrm{C}$ and poured over with $160 \mathrm{~mL}$ of $\mathrm{SiCl}_{4}$. The autoclave was sealed, placed into an electric tubular oven and kept at $280-300^{\circ} \mathrm{C}$ for $5 \mathrm{~h}$ being stirred by rocking. Then the working autoclave contents was transferred through the filter into the receiving autoclave, which was cooled and opened. The contents of the receiving autoclave was filtered, the precipitate $(\sim 4 \mathrm{~g})$ separated and analyzed. The filtrate $\left(\mathrm{SiCl}_{4}\right)$ was recovered by distillation and reused. The residue remaining in the working autoclave was also extracted with acetonitrile, filtered, the filtrate evaporated and the residue analyzed. It consists mainly of ferrum chloride with only negligible amount of niobium pentachloride. The cake ( $\sim 60 \mathrm{~g})$ was washed with water, dried and analyzed. The results are given in Table 6. 
Table 6. Contents of various metals after chlorination of low-grade niobium ore concentrate with $\mathrm{SiCl}_{4}$.

\begin{tabular}{l|c|c|c}
\hline \multirow{2}{*}{ Metal } & \multirow{2}{*}{$\begin{array}{c}\text { Ore } \\
\text { concentrate }\end{array}$} & \multicolumn{2}{|c}{ Cake after chlorination } \\
\cline { 3 - 4 } & 3.66 & at $280^{\circ} \mathrm{C}$ & at $300^{\circ} \mathrm{C}$ \\
\hline $\mathrm{Nb}$ & 2.06 & $1.076(0.47)^{*}$ \\
$\mathrm{Fe}$ & 21.5 & 1.96 & 5.74 \\
$\mathrm{Sr}$ & 1.58 & 0.22 & 0.9 \\
$\mathrm{Ta}$ & 0.088 & 0.033 & $0.1(0.065)^{*}$ \\
$\mathrm{La}$ & 0.087 & 0.042 & 0.14 \\
$\mathrm{Mn}$ & 0.56 & 0.01 & 0.07 \\
$\mathrm{Ti}$ & 0.52 & 0.1 & 0.24 \\
$\mathrm{Ba}$ & 0.11 & 0.03 & $\mathrm{n} / \mathrm{d}$ \\
$\mathrm{Ce}$ & 0.24 & 0.1 & 0.24 \\
\hline
\end{tabular}

* Under vigorous stirring, reaction time $30 \mathrm{~min}$.

\subsection{Analytical Procedure}

Determination of $\mathrm{Nb}, \mathrm{Ta}$, and some of the accompanying rock-forming elements was performed by X-ray fluorescence analysis on a VRA-30 (Carl Zeiss) spectrometer with X-ray tube Ag anode operated at $50 \mathrm{kV}$ and $20 \mathrm{~mA}$, and a S4 Pioneer (Bruker AXS) spectrometer with X-ray tube $\mathrm{Rh}$ anode operated at $50 \mathrm{kV}$ and $40 \mathrm{~mA}$. The samples were prepared by two procedures. (1) For VRA-30: the powdered samples were poured into a cuvette with the bottom shielded by 10 $\mu \mathrm{m}$ polypropylene film and exposed in air. (2) For S4 Pioneer: $300 \mathrm{mg}$ of the sample was mixed with $2 \mathrm{~g}$ of powdered cellulose, pressed pellets and exposed in vacuum. $\mathrm{Nb} \mathrm{K}_{\alpha}$ and $\mathrm{Ta} \mathrm{L}_{\alpha}$ lines were used as analytical lines. For calibration, a set of standard reference samples with the content of the analyzed elements in the range of $0.08-21.5 \% \mathrm{Nb}_{2} \mathrm{O}_{5} ; 0.147-34 \% \mathrm{Ta}_{2} \mathrm{O}_{5}$ was used. To take into account the matrix composition effect, the intensity of the line of incoherently scattered radiation of the tube anode was measured $\left(\mathrm{AgK}_{\alpha}\right.$ and $\mathrm{RhK}_{\alpha}$ Compton line for VRA-30 and S4 Pioneer, respectively). The analytical signal was taken to be equal to the ratio of the analytical lines to the line of the tube anode incoherent scattering. The calibration curve was determined using the multiple regression procedure available in the spectrometer software. The standard deviation from the calibration curve for $\mathrm{Nb}$ and $\mathrm{Ta}$ is ca. $0.1 \%$. To estimate the content of the rock-forming elements the procedure available in the S4 Pioneer spectrometer software was used.

\section{RESULTS and DISCUSSION}

\subsection{Chlorination of $\mathrm{Nb}_{2} \mathrm{O}_{5}$ with $\mathrm{CCl}_{4}$}

As follows from the experiments with $\mathrm{Nb}_{2} \mathrm{O}_{5}$ performed under different conditions, the ratio between $\mathrm{NbOCl}_{3}$ and $\mathrm{NbCl}_{5}$ is changed in favor of the latter with temperature, so that at $\sim 250^{\circ} \mathrm{C}$ $\mathrm{NbOCl}_{3}$ is formed in substantial amounts whereas at temperatures close to or above $300^{\circ} \mathrm{C} \mathrm{NbCl}_{5}$ is practically the only product of chlorination. In a separate study, we found that the use of a 2:1 mixture of $\mathrm{CCl}_{4}: \mathrm{CH}_{3} \mathrm{CN}$ instead of pure $\mathrm{CCl}_{4}$ (in the same manner as described in Section 2.3) sharply decreases the amount of phosgene formed, so that it cannot be detected by IR spectroscopy. 


\subsection{Chlorination of Columbites and Pyrochlores with $\mathbf{C C l}_{\mathbf{4}}$}

The data of Table 1 show that the average degree of extraction of niobium and tantalum from ore concentrates is not less than $97 \%$. It clearly demonstrates that the elaborated autoclave technology is effective for extraction of these metals from their low-grade concentrates. This allows one to work with gravitation concentrates and avoid operations such as froth flotation and magnetic separation.

\subsection{Chlorination of Metal Oxides with $\mathrm{SiCl}_{4}$}

The results of $\mathrm{Nb}_{2} \mathrm{O}_{5}$ chlorination under various conditions are given in Table 2 and the content of different oxides before and after chlorination in Table 3. The main impurities in the starting technical grade $\mathrm{Nb}_{2} \mathrm{O}_{5}$ were $\mathrm{WO}_{3}, \mathrm{Fe}_{2} \mathrm{O}_{3}, \mathrm{As}_{2} \mathrm{O}_{3}$ and $\mathrm{SnO}_{2}$. Sulfur and phosphorus are also present in amounts of $1-2 \%$. The final product, $\mathrm{NbCl}_{5}$, prepared by sublimation of the crude product of chlorination, is of $>97 \%$ purity and contains $\sim 2 \%$ of $\mathrm{WO}_{3}$ and traces of $\mathrm{SiO}_{2}$ and $\mathrm{ZrO}_{2}$. Other elements could not be detected by XRF method. As can be seen from Table 2, after chlorination the main impurities either remain in the acetonitrile insoluble residue (tin) or are not sublimed and therefore can be separated from the target product completely (iron) or to a substantial degree (tungsten). The residue remaining after extraction with acetonitrile represents sand contaminated by oxides and sulfates of iron, tin and arsenic. Noteworthy is the extraction of zinc, nickel, chromium and tungsten, whose content in the acetonitrile extract exceeds their content in the starting material. Of special interest may be the extraction of uranium and thorium, which are also accumulated in the acetonitrile extract but do not pass into the target product $\left(\mathrm{NbCl}_{5}\right)$ after sublimation.

The results of Table 2 (runs 4 and 5) clearly demonstrate the importance of mass transfer in the process: the yield of niobium chlorides increases more than twice; therefore, further experiments were performed in the apparatus shown in Fig. 1.

As compared to chlorination with $\mathrm{CCl}_{4}$, the optimal temperature for chlorination with $\mathrm{SiCl}_{4}$ is notably lower, $210^{\circ} \mathrm{C}$ (run 7 in Table 2) vs. $250-290^{\circ} \mathrm{C}$ for experiments in Table 1.

The results of $\mathrm{Ta}_{2} \mathrm{O}_{5}$ chlorination under various conditions are given in Table 4 and the content of different elements after chlorination in Table 5. The final product, $\mathrm{TaCl}_{5}$, prepared by sublimation of the crude product of chlorination, is also of $>97 \%$ purity and contains $\sim 2 \%$ of $\mathrm{SiO}_{2}$ and traces of $\mathrm{WO}_{3}$ and $\mathrm{CuO}$. The temperature for successful chlorination of $\mathrm{Ta}_{2} \mathrm{O}_{5}$ is somewhat higher than for $\mathrm{Nb}_{2} \mathrm{O}_{5}\left(245^{\circ} \mathrm{C}\right.$ vs. $\left.210^{\circ} \mathrm{C}\right)$.

\subsection{Chlorination of Low-Grade Niobium Ore Concentrate with $\mathrm{SiCl}_{\mathbf{4}}$}

A series of experiments performed on a low-grade niobium concentrate containing $\sim 3.7 \%$ of $\mathrm{Nb}$ and only trace amounts of Ta allowed us to determine the optimal parameters of the process. The optimal ratio of the components, concentrate: $\mathrm{SiCl}_{4}$, is $1: 3$. The optimal temperature is $300^{\circ} \mathrm{C}$, below $270^{\circ} \mathrm{C}$ practically no chlorination of the target metal occurs, the yield of $\mathrm{NbCl}_{5}$ is $<1 \%$. The results of chlorination are given in Table 6 . The degree of extraction at $280^{\circ} \mathrm{C}$ is as low as $45 \%$. At $300^{\circ} \mathrm{C}$ it increases to $71 \%$, and vigorous stirring of the mixture in the autoclave allows to reach $87 \%$ extraction of niobium. The fact that the maximum degree of extraction so far attained in chlorination with $\mathrm{SiCl}_{4}(87 \%)$ is still less than with $\mathrm{CCl}_{4}(97 \%)$ is, most probably, due to formation of $\mathrm{SiO}_{2}$ for the former chlorinating agent, which is precipitated on the surface of the ore concentrate and hinders penetration of the liquid chlorinating agent $\mathrm{SiCl}_{4}$ into the pores of the chlorinated mineral. 


\subsection{Thermodynamic Analysis}

Schematically the chemical process can be expressed by either of the following equations or their combination (in the presence or absence of crystallization water; $M$ in the equations below denotes $\mathrm{Nb}$ or $\mathrm{Ta}$ ):

$$
\begin{gathered}
\mathrm{M}_{2} \mathrm{O}_{5}+\mathrm{H}_{2} \mathrm{O}+3 \mathrm{SiCl}_{4} \longrightarrow 2 \mathrm{MCl}_{5}+2 \mathrm{HCl}+3 \mathrm{SiO}_{2} \\
2 \mathrm{M}_{2} \mathrm{O}_{5}+5 \mathrm{SiCl}_{4} \longrightarrow 4 \mathrm{MCl}_{5}+5 \mathrm{SiO}_{2} \\
2 \mathrm{M}_{2} \mathrm{O}_{5}+3 \mathrm{SiCl}_{4} \longrightarrow 4 \mathrm{MOCl}_{3}+3 \mathrm{SiO}_{2}
\end{gathered}
$$

An interesting question is why chlorination with $\mathrm{SiCl}_{4}$ occurs as easily as, or even at lower temperatures than, with $\mathrm{CCl}_{4}$ ? Equations (4)-(6), which are similar to equations (1)-(3) can be written for the latter process:

$$
\begin{gathered}
\mathrm{M}_{2} \mathrm{O}_{5}+\mathrm{H}_{2} \mathrm{O}+3 \mathrm{CCl}_{4} \longrightarrow 2 \mathrm{MCl}_{5}+2 \mathrm{HCl}+3 \mathrm{CO}_{2} \\
2 \mathrm{M}_{2} \mathrm{O}_{5}+5 \mathrm{CCl}_{4} \longrightarrow 4 \mathrm{MCl}_{5}+5 \mathrm{CO}_{2} \\
2 \mathrm{M}_{2} \mathrm{O}_{5}+3 \mathrm{CCl}_{4} \longrightarrow 4 \mathrm{MOCl}_{3}+3 \mathrm{CO}_{2}
\end{gathered}
$$

Calculation of the differences of thermal effects $\Delta \Delta \mathrm{H}=\Delta \mathrm{H}^{\mathrm{o}}\left(\mathrm{CCl}_{4}\right)-\Delta \mathrm{H}^{\mathrm{o}}\left(\mathrm{SiCl}_{4}\right)$ and of free energies $\Delta \Delta \mathrm{G}=\Delta \mathrm{G}^{\mathrm{O}}\left(\mathrm{CCl}_{4}\right)-\Delta \mathrm{G}^{\mathrm{O}}\left(\mathrm{SiCl}_{4}\right)$ for chlorination in $\mathrm{CCl}_{4}$ and in $\mathrm{SiCl}_{4}$ in the gas and the liquid phase with respect to one molecule of a metal oxide, using the values of $\Delta \mathrm{H}_{\mathrm{f}}^{\mathrm{o}}\left(\mathrm{CCl}_{4}\right)_{\mathrm{g}}-100.4$, $\Delta \mathrm{H}_{\mathrm{f}}^{\mathrm{o}}\left(\mathrm{CCl}_{4}\right)_{1}-132.6, \quad \Delta \mathrm{G}_{\mathrm{f}}^{\mathrm{o}}\left(\mathrm{CCl}_{4}\right)_{\mathrm{g}}-58.2, \quad \Delta \mathrm{G}_{\mathrm{f}}^{\mathrm{o}}\left(\mathrm{CCl}_{4}\right)_{1}-62.8, \quad \Delta \mathrm{H}_{\mathrm{f}}{ }^{\mathrm{o}}\left(\mathrm{SiCl}_{4}\right)_{\mathrm{g}}-609.6, \quad \Delta \mathrm{H}_{\mathrm{f}}{ }^{\mathrm{o}}\left(\mathrm{SiCl}_{4}\right)_{1}$ -640.2, $\Delta \mathrm{G}_{\mathrm{f}}^{\mathrm{o}}\left(\mathrm{SiCl}_{4}\right)_{\mathrm{g}}-569.9, \Delta \mathrm{G}_{\mathrm{f}}^{\mathrm{o}}\left(\mathrm{SiCl}_{4}\right)_{1}-572.8, \Delta \mathrm{H}_{\mathrm{f}}^{\mathrm{o}}\left(\mathrm{CO}_{2}\right)_{\mathrm{g}}-393.3, \Delta \mathrm{G}_{\mathrm{f}}^{\mathrm{o}}\left(\mathrm{CO}_{2}\right)_{\mathrm{g}}-394.6$, $\Delta \mathrm{H}_{\mathrm{f}}{ }^{\mathrm{o}}\left(\mathrm{SiO}_{2}\right)_{\mathrm{s}}-859.4, \Delta \mathrm{G}_{\mathrm{f}}{ }^{\mathrm{o}}\left(\mathrm{SiO}_{2}\right)_{\mathrm{s}}-856.7, \Delta \mathrm{H}_{\mathrm{f}}{ }^{\mathrm{o}}\left(\mathrm{COCl}_{2}\right)_{\mathrm{g}}-220.9, \Delta \mathrm{G}_{\mathrm{f}}{ }^{\mathrm{o}}\left(\mathrm{COCl}_{2}\right)_{\mathrm{g}}-206.7 \mathrm{~kJ} / \mathrm{mol}$ taken from [16] gives the values summarized in Table 7.

Table 7. Thermodynamic parameters $\left(\mathrm{kJ} \mathrm{mol}^{-1}\right)$ for chlorination of metal oxides with $\mathrm{CCl}_{4}$ and $\mathrm{SiCl}_{4}$

\begin{tabular}{l|r|r|r|r}
\hline \multirow{2}{*}{ Reaction } & \multicolumn{2}{|c|}{$\Delta \Delta \mathrm{H}$} & \multicolumn{2}{c}{$\Delta \Delta \mathrm{G}$} \\
\cline { 2 - 5 } & \multicolumn{1}{c|}{ gas } & liquid & \multicolumn{1}{c}{ gas } & \multicolumn{1}{c}{ liquid } \\
\hline eq(4) - eq(1) & -129.3 & -124.5 & -148.8 & -143.7 \\
eq(5) - eq(2) & -107.8 & -103.8 & -124.0 & -119.8 \\
eq(6) - eq(3) & -64.6 & -62.2 & -74.4 & -71.8 \\
eq(7) - eq(2) & +323.2 & +327.2 & +345.8 & +350.0 \\
eq(8) - eq(3) & +194.0 & +196.4 & +207.4 & +210.0 \\
\hline
\end{tabular}

For simplicity, we neglect here the temperature dependence of thermal effects, since, first, the temperature is much lower than usual temperatures for conventional carbochlorination, and, 
second, when calculating the $\Delta \Delta \mathrm{H}$ and $\Delta \Delta \mathrm{G}$ values, the temperature effects are largely annihilated by subtraction. The values of $\Delta \Delta \mathrm{H}$ and $\Delta \Delta \mathrm{G}$ are the same for chlorination of both niobium and tantalum pentoxides since they do not depend on the nature of the chlorinated metal oxide. Of course, the data in Table 7 can give only an approximate estimation of thermodynamic parameters of the reactions proceeding at high temperatures and pressures. Nevertheless, because of large negative or positive values, these data can be considered, at least, qualitatively, to reflect the behavior of real systems.

The following conclusions can be drawn from analysis of Table 7. First, the values of $\Delta \Delta \mathrm{H}$ and $\Delta \Delta \mathrm{G}$ have the same sign and do not differ much in value. Second, the $\Delta \Delta \mathrm{G}$ values are more negative than the corresponding $\Delta \Delta \mathrm{H}$ values for the pairs of reactions (4)-(1), (5)-(2), (6)-(3), and more positive for the pairs of reactions (7)-(2) and (8)-(3). The fact that the $\Delta \Delta \mathrm{H}$ and $\Delta \Delta \mathrm{G}$ values in Table 7 are negative for the corresponding pairs of reactions (1)-(6) means that the process of chlorination should be more exothermic for $\mathrm{CCl}_{4}$ as a chlorination agent, provided that it is completely transformed into $\mathrm{CO}_{2}$. This seems to be in apparent contradiction with the experimental observations, which showed that with $\mathrm{SiCl}_{4}$ the chlorination occurs under similar or even milder conditions. However, the contradiction is removed if we consider that $\mathrm{CCl}_{4}$ is capable of being also partly dechlorinated to $\mathrm{COCl}_{2}$, whereas no similar process is possible for $\mathrm{SiCl}_{4}$. Dichlorosilanone $\mathrm{Cl}_{2} \mathrm{Si}=\mathrm{O}$ does not exist as a stable compound but only formed as a reactive intermediate species by copyrolysis of hexamethyldisiloxane with tetrachlorosilane [17]. It was also studied theoretically as an elusive intermediate of hydrolysis of $\mathrm{SiCl}_{4}$ [18]. With $\mathrm{CCl}_{4}$, the reactions of chlorination of metal oxides with only partial dechlorination of $\mathrm{CCl}_{4}$ to $\mathrm{COCl}_{2}$ can be written as follows:

$$
\begin{aligned}
& \mathrm{M}_{2} \mathrm{O}_{5}+5 \mathrm{CCl}_{4} \longrightarrow 2 \mathrm{MCl}_{5}+5 \mathrm{COCl}_{2} \\
& \mathrm{M}_{2} \mathrm{O}_{5}+3 \mathrm{CCl}_{4} \longrightarrow 2 \mathrm{MOCl}_{3}+3 \mathrm{COCl}_{2}
\end{aligned}
$$

The highly positive values of $\Delta \Delta \mathrm{H}$ and $\Delta \Delta \mathrm{G}$ in Table 7 clearly demonstrate that chlorination with $\mathrm{SiCl}_{4}$ by reactions (2) and (3) is much more preferable than that with $\mathrm{CCl}_{4}$ by reactions (7) and (8). Therefore, even if the process of dechlorination of $\mathrm{CCl}_{4}$ to $\mathrm{COCl}_{2}$ comprises a third part of its dechlorination to $\mathrm{CO}_{2}$, the total process will be less exothermic than that with $\mathrm{SiCl}_{4}$.

Niobium and tantalum pentachlorides after purification by sublimation can be used not only as starting materials for preparation of pure metals but also as catalysts for various reactions, like Friedel-Crafts acylation and Sakurai-Hosomi reaction of acetals [19], ring opening of epoxides [20] catalyzed by $\mathrm{NbCl}_{5}$, or preparation of higher esters of acrylic acid [21] or polymers with high oxygen permeability [22] catalyzed by $\mathrm{TaCl}_{5}$.

\section{CONCLUSIONS}

New processes of conversion of niobium and tantalum oxides into their pentachlorides by the reaction with silicon tetrachloride under pressure at temperatures of $210-290^{\circ} \mathrm{C}$ were developed and a new autoclave technology for extraction of niobium and tantalum from their low-grade ore concentrates was elaborated. The new technology is based on chlorination of low-grade niobium and tantalum ore concentrates with carbon tetrachloride or silicon tetrachloride under pressure at moderate temperatures and represents an alternative to traditional carbochlorination process. It 
allows (i) to decrease the temperature of the process from $\sim 1000^{\circ} \mathrm{C}$ to $250-300^{\circ} \mathrm{C}$ and, therefore, minimize energy consumption; (ii) to avoid the use of elemental chlorine; (iii) to remove (with $\mathrm{SiCl}_{4}$ as a chlorinating agent) the formation of environmentally hazardous exhausts such as toxic and ozone depleting compounds (phosgene, carbon monoxide, chlorohydrocarbons) unavoidable in traditional carbochlorination process; (iv) to work with low-grade gravitation concentrates that decreases the costs for enrichment the ore since it allows to exclude froth flotation and magnetic separation; and (v) to reuse a substantial part of the chlorinating agents.

\section{ACKNOWLEDGEMENT}

The authors are grateful to the Irkutsk Scientific Center for financial support of this work.

\section{REFERENCES}

[1] Mehra, O. K., Zahed H. S., and Jena, P. K., 1966, "Kinetics of the chlorination of niobium pentoxide with chlorine in presence of excess graphite powder" Trans. Indian Inst. Met., Vol. 19, pp. 53-56.

[2] Mehra, O. K., and Jena, P. K., 1967, "Kinetics of the chlorination of tantalum-pentoxide with chlorine in the presence of excess graphite powder", Trans. Indian Inst. Met., Vol. 20, pp. 210-212.

[3] Meubus, P., 1979, "High temperature chlorination kinetics of a niobium pyrochlore", Metall. Trans., Vol. 10B, No. 1, pp. 93-101.

[4] Ruiz, M. del C., Gonzalez, J., and Rivarola, J., 1997, "Carbochlorination of Argentinian tantalo-columbites”, Canad. Metallurg. Quart., Vol. 36, No. 2, pp. 103-110.

[5] Gonzalez, J., Gennari, F., Bohé, A., Ruiz, M. del C., Rivarola, J., and Pasquevich, D. M., 1998, "Chlorination of a niobium and tantalum ore", Thermochim. Acta, Vol. 311, No. 1-2, pp. 61-69.

[6] Gonzalez, J., Gennari, F., Ruiz, M. del C., Bohé, A., and Pasquevich, D. M., 1998, "Kinetics of the carbochlorination of columbite", Trans. Instn. Min. Metall. (Sect. C:

Mineral Process. Extr. Metall.), Vol. 107, pp. 130-138.

[7] Gonzalez, J., Bohé, A., Pasquevich, D. M., and Ruiz, M. del C., 2002, " $\beta-\mathrm{Ta}_{2} \mathrm{O}_{5}$ carbochlorination with different types of carbon”, Canad. Metallurg. Quart., Vol. 41, No. 1, pp. 29-40.

[8] Ruiz, M. del C., Gonzalez, J., and Rivarola, J., 2004, "Kinetics of chlorination of tantalum pentoxide in mixture with sucrose carbon by chlorine gas", Metall. Mater. Trans., Vol. 35B, No. 3, pp. 439-448.

[9] Allain, E., Djona, M., and Gaballah, I., 1997, "Kinetics of chlorination and carbochlorination of pure tantalum and niobium pentoxides", Metall. Mater. Trans., Vol. 28B, No. 2, pp. 223-233.

[10] Gaballah, I., Allain, E., and Djona, M., 1997, "Extraction of tantalum and niobium from tin slags by chlorination and carbochlorination", Metall. Mater. Trans., Vol. 28B, No. 3, pp. 359-369.

[11] Jena, P.K., Brocchi, E. A., and Garcia, R.I., 1997, "Kinetics of chlorination of niobium pentoxide by carbon tetrachloride", Metall. Mater. Trans., Vol. 28B, No. 1, pp. 39-45. 
[12] Jena, P. K., Brocchi, E. A., and Lima, M.P.A.C., 2001, "Studies on the kinetics of carbon tetrachloride chlorination of tantalum pentoxide", Metall. Mater. Trans., Vol. 32B, No. 5, pp. 801-810.

[13] Chernykh, V.P., RF Patent No. 2033415. 1995. Bull. izobr. No. 11.

[14] Garmazov, Yu. L., Turchaninov, V. K., Danilevich, Yu. S., and Shainyan, B. A., RF Patent No. 2292301. 2007. Bull. izobr. No. 3.

[15] Garmazov, Yu. L., Turchaninov, V. K., Danilevich, Yu. S., and Shainyan, B. A., RF Patent No. 2292302. 2007. Bull. izobr. No. 3.

[16] Chase, M. W., Jr., 1998, NIST-JANAF Themochemical Tables, $4^{\text {th }}$ Ed. J. Phys. Chem. Ref. Data, Monograph 9, 1951 pp.

[17] Chernyshev, E. A., Krasnova, T. L., Sergeev A. P., and Abramova, E. S., 1997, "Siloxanes as sources of silanones", Russ. Chem. Bull., Vol. 46, No. 9, pp. 1586-1589.

[18] Ignatov, S. K., Sennikov, P. G., Razuvaev, A. G., Chuprov, L. A., Schrems, O., and Ault, B. S., 2003, "Theoretical study of the reaction mechanism and role of water clusters in the gas-phase hydrolysis of $\mathrm{SiCl}_{4}$ ", J. Phys. Chem., Vol. 107A, No. 41, pp. 8705-8713.

[19] Arai, S., Sudo, Y., and Nishida, A., 2005, "Niobium pentachloride-silver perchlorate as an efficient catalyst in the Friedel-Crafts acylation and Sakurai-Hosomi reaction of acetals", Tetrahedron, Vol. 61, No. 19, pp. 4639-4642.

[20] Narsaiah, A.V., Sreenu, D., and Nagaiah, K., 2006, "Efficient synthesis of $\beta$-amino alcohols catalyzed by niobium pentachloride: regioselective ring opening of epoxides with aromatic amines", Synth. Commun., Vol. 36, No. , pp. 3183-3189.

[21] Fried, H. E., and Johnson, T. H., US Patent No. 5066829. Publ. 19.11.1991.

[22] Masuda, T., Isobe, E., Higashimura, T., and Takada, K., 1983, "Poly[1-(trimethylsilyl)-1propyne]: a new high polymer synthesized with transition-metal catalysts and characterized by extremely high gas permeability", J. Am. Chem. Soc., Vol. 105, No. 25, pp. 7473-7474. 